\title{
Strong Interactive Effects of Warming and Insect Herbivory on Soil Carbon and Nitrogen Dynamics at Subarctic Tree Line
}

\author{
Nele Meyer ${ }^{1,2 t}$, Tarja Silfver ${ }^{3,4 t}$, Kristiina Karhu ${ }^{1,5,6 *}$, Kristiina Myller ${ }^{7}$, Outi-Maaria Sietiö ${ }^{1}$, \\ Eero Myrsky ${ }^{8}$, Elina Oksanen ${ }^{7}$, Matti Rousi ${ }^{6}$ and Juha Mikola ${ }^{3,4,6}$ \\ ${ }^{1}$ Department of Forest Sciences, Faculty of Agriculture and Forestry, University of Helsinki, Helsinki, Finland, ${ }^{2}$ Department \\ of Soil Ecology, University of Bayreuth, Bayreuth, Germany, ${ }^{3}$ Faculty of Biological and Environmental Sciences, University \\ of Helsinki, Lahti, Finland, ${ }^{4}$ Kevo Subarctic Research Institute, Biodiversity Unit of the University of Turku, Utsjoki, Finland, \\ ${ }^{5} \mathrm{Helsinki}$ Institute of Life Science (HiLIFE), Faculty of Agriculture and Forestry, University of Helsinki, Helsinki, Finland, \\ ${ }^{6}$ Natural Resources Institute Finland (Luke), Helsinki, Finland, ${ }^{7}$ Department of Environmental and Biological Sciences, \\ University of Eastern Finland, Joensuu, Finland, ${ }^{8}$ Arctic Centre, University of Lapland, Rovaniemi, Finland
}

OPEN ACCESS

Edited by:

Andreas Schindlbacher, Austrian Research Centre for Forests (BFW), Austria

Reviewed by:

Xiao-Tao Lu, Institute of Applied Ecology, Chinese Academy of Sciences (CAS), China Alan Feest. University of Bristol, United Kingdom

*Correspondence: Kristiina Karhu kristiina.karhu@helsinki.fi

tThese authors share first authorship

Specialty section: This article was submitted to Forest Soils,

a section of the journal Frontiers in Forests and Global Change

Received: 09 September 2021 Accepted: 22 October 2021 Published: 11 November 2021

Citation:

Meyer N, Silfver T, Karhu K, Myller K, Sietiö O-M, Myrsky E, Oksanen E, Rousi M and Mikola J

(2021) Strong Interactive Effects of Warming and Insect Herbivory on Soil Carbon and Nitrogen Dynamics at Subarctic Tree Line. Front. For. Glob. Change 4:773223. doi: 10.3389/ffgc.2021.773223
Warming will likely stimulate Arctic primary production, but also soil $\mathrm{C}$ and $\mathrm{N}$ mineralization, and it remains uncertain whether the Arctic will become a sink or a source for $\mathrm{CO}_{2}$. Increasing insect herbivory may also dampen the positive response of plant production and soil $\mathrm{C}$ input to warming. We conducted an open-air warming experiment with Subarctic field layer vegetation in North Finland to explore the effects of warming $\left(+3^{\circ} \mathrm{C}\right)$ and reduced insect herbivory (67\% reduction in leaf damage using an insecticide) on soil $\mathrm{C}$ and $\mathrm{N}$ dynamics. We found that plant root growth, soil $\mathrm{C}$ and $\mathrm{N}$ concentrations, microbial biomass $\mathrm{C}$, microbial activity, and soil $\mathrm{NH}_{4}{ }^{+}$availability were increased by both warming and reduced herbivory when applied alone, but not when combined. Soil $\mathrm{NO}_{3}{ }^{-}$ availability increased by warming only and in-situ soil respiration by reduced herbivory only. Our results suggest that increasing $C$ input from vegetation under climate warming increases soil $\mathrm{C}$ concentration, but also stimulates soil $\mathrm{C}$ turnover. On the other hand, it appears that insect herbivores can significantly reduce plant growth. If their abundance increases with warming as predicted, they may curtail the positive effect of warming on soil $\mathrm{C}$ concentration. Moreover, our results suggest that temperature and herbivory effects on root growth and soil variables interact strongly, which probably arises from a combination of $\mathrm{N}$ demand increasing under lower herbivory and soil mineral $\mathrm{N}$ supply increasing under higher temperature. This may further complicate the effects of rising temperatures on Subarctic soil $\mathrm{C}$ dynamics.

Keywords: primary production, root growth, climate warming, microbial biomass, soil respiration, soil organic matter

\section{INTRODUCTION}

The Arctic is predicted to experience rising temperatures of $4-7^{\circ} \mathrm{C}$ by the end of this century (IPCC, 2014). This may increase plant production (Pouliot et al., 2009; Beck and Goetz, 2011; Natali et al., 2011; Elmendorf et al., 2012) and advance the Subarctic tree line (Harsch et al., 2009) as these are generally assumed to be suppressed by low temperatures (Körner and Paulsen, 2004). For 
instance, Tømmervik et al. (2004) and Rundqvist et al. (2011) reported substantial increases in the abundance of shrubs and trees, such as dwarf birch (Betula nana) and mountain birch (B. pubescens ssp. czerepanovii), over the last decades at the northern Scandinavian tree line. One could assume that such "greening" would enhance $\mathrm{CO}_{2}$ uptake and the carbon $(\mathrm{C})$ sink in these areas. However, soil $\mathrm{C}$ mineralization also depends on temperature and is predicted to increase upon warming. For instance, Kätterer et al. (1998) and Meyer et al. (2018) showed that the heterotrophic soil respiration on average doubles with a $10^{\circ} \mathrm{C}$ rise in temperature, and Kirschbaum (1995) and Mikan et al. (2002) pointed out that temperature sensitivity is likely to be even larger at high latitudes, where warming occurs at low temperatures. The fate of the $\mathrm{C}$ sink in the Arctic will therefore depend on how the balance between $\mathrm{C}$ accrual through plant production and $\mathrm{C}$ loss through soil organic matter (SOM) decomposition will change under a warming climate. Some studies suggest that the Arctic will become a stronger $\mathrm{C}$ sink (Sistla et al., 2013; Silfver et al., 2020) while others suggest it will become a C source (Oechel et al., 1993; Lundin et al., 2016).

A major uncertainty in this context is whether greening as such has a positive or negative effect on the soil C sink. Models predict that the enhanced primary production will increase organic matter input into the soil and thereby strengthen the soil C sink (Qian et al., 2010). However, Hartley et al. (2012) reported an opposite effect when they compared a shrub dominated tundra to a mountain birch forest of higher plant production. A likely explanation for their finding is that microbial $\mathrm{N}$ demand increased in forest soil due to increased exudation of labile $\mathrm{C}$ from roots (Hartley et al., 2012). In such situation, microbes achieve their nutrient demand by "N mining," i.e., through accelerated decomposition of older SOM (Moorhead and Sinsabaugh, 2006; Craine et al., 2007). This is called a priming effect (Kuzyakov et al., 2000) and is suggested to cause immense losses of soil C once trees colonize former shrub dominated tundra (Dijkstra and Cheng, 2007; Hartley et al., 2012). Supporting this idea, lower soil C contents have been reported in forest soils in comparison to tundra and shrubland soils in several studies (Wilmking et al., 2006; Hartley et al., 2012; Parker et al., 2015). However, opposite effects, such as decreasing soil C stocks with increasing distance to a tree (Friggens et al., 2020a), and neutral effects (Kammer et al., 2009; Zimmermann et al., 2010) have also been reported for tree line environments. For shrub vegetation, Ylänne et al. (2015) reported increasing soil C stocks in response to warminginduced greater plant growth. Apparently, to accurately predict the fate of soil $\mathrm{C}$ sink upon Arctic greening requires better understanding of the various mechanisms that take place in these situations. Moreover, while there is data accumulating of the effects of tree line advancement on soil C dynamics, less is known of the effects of the increasing growth of tundra and field layer vegetation in these areas.

Predicting the overall C sink strength is also complicated by doubts whether plants will actually grow better and induce larger C sequestration under warmer conditions. Studies have shown that low soil fertility may significantly hinder the positive effects of warmer climate on tree growth and survival in the Subarctic (Richardson et al., 2002; Rousi et al., 2018). This suggests that increased nutrient mineralization along with warming may be a prerequisite for significantly increasing $C$ sequestration in northern areas with low nutrient availability. Another important, but often overlooked factor is that warming will likely lead to increased insect herbivore pressure, both at the outbreak (Neuvonen et al., 1999; Hagen et al., 2007; Jepsen et al., 2008) and background intensities (Kozlov, 2008; Wolf et al., 2008; Currano et al., 2010; Kozlov et al., 2015). In large areas across the Finnish mountain birch zone, the tree line has regressed due to moth outbreaks (Holtmeier and Broll, 2006; Van Bogaert et al., 2011) and recent findings suggest that even the background level of insect herbivory can significantly dampen the positive effect of warming on the $\mathrm{CO}_{2}$ uptake potential of Subarctic field layer vegetation (Silfver et al., 2020). Moreover, such negative effects on plant performance may further be aggravated by decreasing plant resistance upon warming (Stark et al., 2015).

Here, we present results from a study, where we examined how warming and the level of insect herbivory interact in affecting soil $\mathrm{C}$ and $\mathrm{N}$ dynamics under field layer vegetation in Subarctic tree line conditions. Using an open-air warming experiment established in a mountain birch forest in northern Finland (Silfver et al., 2020), we investigated the responses of field layer vascular plant shoot and root growth, soil microbial biomass and activity, and soil $\mathrm{C}$ and $\mathrm{N}$ concentrations and mineralization to warming and reduced insect herbivory. Using the same experimental set-up and treatments, Silfver et al. (2020) showed that plant growth and ecosystem $\mathrm{CO}_{2}$ uptake were significantly increased by both warming and reduced herbivory. Based on this observation, we hypothesized that the increased plant growth either due to warming or reduced herbivory - will increase soil $\mathrm{C}$ input and the size and activity of soil microbial biomass. This will then lead to increased mineralization of organic $\mathrm{C}$ and $\mathrm{N}$, manifested as decreasing soil $\mathrm{C}$ concentrations and increasing inorganic $\mathrm{N}$ concentrations.

\section{MATERIALS AND METHODS}

\section{Study Site}

The study site is located in a mountain birch forest at the Turku University Kevo Subarctic Research Institute in Utsjoki, Finland $\left(69^{\circ} 45^{\prime} \mathrm{N}, 27^{\circ} 01^{\prime} \mathrm{E}, 104 \mathrm{~m}\right.$ a.s.l.). The mean annual temperature at the site was $-1.3^{\circ} \mathrm{C}$, and the mean annual precipitation was $354 \mathrm{~mm}$, during reference years 1981-2010 (Finnish Meteorological Institute). The soil at the site is a Podzol with a clear 2-7 cm deep organic layer, sandy mineral soil and randomly placed rocks. The study area only includes mountain birch trees, but sporadic Scots pine (Pinus sylvestris) trees grow nearby. Before establishing the experiment, adult mountain birches were removed from the canopy layer, while the field layer was left intact. An area of $220 \mathrm{~m}^{2}$ was fenced for the experiment.

\section{Experimental Set-Up}

For the experiment, 20 treatment plots $(0.75 \mathrm{~m} \times 1 \mathrm{~m}$ each) were randomly placed within the fenced area in 2016. Five replicate blocks were established and four treatment plots were included in each block. Treatments included two 
levels of open-air warming (ambient, $+3^{\circ} \mathrm{C}$ ) and two levels of insect herbivory (natural, reduced) in a fully factorial $2 \times 2$ design. The four treatment combinations (ambient temperature with natural herbivory, ambient temperature with reduced herbivory, elevated temperature with natural herbivory, elevated temperature with reduced herbivory) were randomly allocated, using a random number generator, to treatment plots in each block $(n=5)$.

To include common Subarctic woody species in the experimental set-up, plantlets of dwarf birch, mountain birch, silver birch (B. pendula) and downy birch (B. pubescens), cloned from individuals of their Subarctic populations (latitudes $67^{\circ} 43^{\prime}$ $\mathrm{N}-69^{\circ} 01^{\prime} \mathrm{N}$ ), were planted, $20 \mathrm{~cm}$ apart, within the field layer vegetation in each plot in mid July 2016 (twelve plantlets in each plot, three genotypes for each species) (Silfver et al., 2020). After planting, the birch plantlets covered $4 \%$ of the plot area, and at the end of the experiment, comprised on average $13 \%$ of vascular plant shoot abundance. Birches will be in focus in other studies, here we consider them as a part of the field layer vegetation.

Warming was realized using ceramic heaters (Elstein-Werk M. Steinmetz $\mathrm{GmbH}$ \& Co., Germany), installed $80 \mathrm{~cm}$ above the ground. Similar dummy heaters were installed in ambient plots. The heaters were controlled by a microprocessorbased feedback system. The system maintained a fixed $3^{\circ} \mathrm{C}$ difference between the ambient and warmed plots using realtime temperature data collected by sensors that were installed $30 \mathrm{~cm}$ above the ground within green metal plates mimicking plant leaves (see more details in Silfver et al., 2020). Air and "fake leaf" temperatures were measured continuously in ambient and warmed plots $(n=3$ for air temperature, $n=5$ for fake leaf temperature). In 2016, heating was turned on in early July, but in later years in spring when the snowcover was $<20 \mathrm{~cm}$. In autumn, warming was turned off when ambient air temperatures started to remain permanently below $-3^{\circ} \mathrm{C}$. On average $( \pm \mathrm{SE}, n=3)$, the plates mimicking plant leaves were $3.3 \pm 0.37^{\circ} \mathrm{C}$, the air $2.3 \pm 0.35^{\circ} \mathrm{C}$ and the soil (at $5 \mathrm{~cm}$ depth) $1.2 \pm 0.15^{\circ} \mathrm{C}$ warmer in heated than ambient plots during the heating periods in 2016-2018 (Silfver et al., 2020).

The herbivore treatment was initiated in the beginning of the 2017 growing season. Reduction of insect herbivores was accomplished by spraying the respective plots once a week with $0.2 \mathrm{~L}$ of $0.1 \%$ synthetic pyrethrin solution (Decis Mega EW50, Bayer Crop Science, Germany) using a portable garden sprayer with a protective tent to eliminate wind drift. An equal amount of water was sprayed on plots with normal herbivory using another sprayer. Synthetic pyrethrin solutions are known to have no side-effects on plant growth or chemistry (Silfver et al., 2013), soil microbial growth (Silfver et al., 2020) or leaf litter decomposition rate (Silfver et al., 2013), and the quantity of $\mathrm{N}$ that could potentially enter the soil as deltamethrin, the active ingredient, degrades is negligible (Silfver et al., 2020). To estimate leaf damage caused by insect herbivores in plots with natural herbivory, and the effects of the insecticide in plots with reduced herbivory, all leaves in each birch plantlet were surveyed in each plot in the middle of August in 2017 and 2019. The herbivore damage of birch leaves was generally low with only $26 \%$ of all leaves in plots with natural herbivory being wounded, and most damaged leaves having only $1-4 \%$ of their leaf area damaged (Silfver et al., 2020). The insecticide application decreased leaf damages on average by $67 \%$, whereas warming had no effect (Silfver et al., 2020). In our experimental approach, we use "normal" and "reduced" herbivory treatments to predict the effect of future increases in herbivory on plant growth and $\mathrm{C}$ dynamics. In Subarctic areas, where leaf damages are currently low (Kozlov, 2008), this approach is justified as the response of plant growth to varying leaf damage has been shown to be linear within a range of $2-16 \%$ leaf area damaged (Zvereva et al., 2012).

\section{Treatment Plot Baseline Information}

To understand the baseline plot-to-plot variation in plant and soil variables, the field layer vegetation, SOM content and soil $\mathrm{NH}_{4}{ }^{+}, \mathrm{NO}_{3}{ }^{-}$, and $\mathrm{PO}_{4}{ }^{3-}$ concentrations were examined for each treatment plot at the beginning of growing season 2017. Lichens and plants were identified to species or genus level and their areal cover was estimated visually. To examine soil characteristics, two to three soil cores (diameter $3 \mathrm{~cm}$, depth $10 \mathrm{~cm}$ or to the nearest rock) were collected from each plot. From each sample, two longitudinal subsamples were taken, one for SOM analyses and the other for the analysis of nutrient concentrations. For each plot, the subsamples were pooled before analysis and used as plot means. SOM was measured as a loss on ignition $\left(550^{\circ} \mathrm{C}, 4 \mathrm{~h}\right)$. For nutrient analysis, the pooled samples were extracted in $70 \mathrm{ml}$ of distilled water, filtered through a glass microfiber filter (Whatman, GE Healthcare Europe $\mathrm{GmbH}$ ) and kept frozen until the $\mathrm{NH}_{4}{ }^{+}, \mathrm{NO}_{3}{ }^{-}$, and $\mathrm{PO}_{4}{ }^{3-}$ concentrations were analyzed using Lachat Quikchem 8000 analyzer (Zellweger Analytics, Inc., Lachat Instruments Division, United States).

Vascular plants (including the birch plantlets) covered 29$83 \%$ of plot area (with Empetrum nigrum, Vaccinium uliginosum, $V$. vitis-idaea, V. myrtillus, and Rhododendron tomentosum as the most abundant species), mosses 3-85\% (Pleurozium schreberi, Hylocomium splendens, and Barbilophozia lycopodioides) and lichens 0-23\% (Nephroma arcticum and Cladonia arbuscula) and the soil OM content, in the top $10 \mathrm{~cm}$ of soil, was $9-38 \%$ of soil dry mass. The variation among the plots for soil $\mathrm{NH}_{4}{ }^{+}, \mathrm{NO}_{3}{ }^{-}$, and $\mathrm{PO}_{4}{ }^{3-}$ concentrations was $0.05-5.79,0.11-30.01$, and $0.03-$ $1.22 \mu \mathrm{g} \mathrm{g}^{-1}$ soil dry mass, respectively. Values of vegetation and soil attributes were utilized as covariates in appropriate statistical models to control the effects of plot-to-plot variation on the response variables.

While the experiment was running, the trimmed mountain birches sprouted and formed bushes in the experimental area. The foliage volume of each bush located less than $2 \mathrm{~m}$ from the center of any plot was estimated by measuring two crossed radii and the height of the bush. The foliage volume was then divided by the distance of the bush from the center of nearby plots to form indices that would describe the strength of the bush effect on each plot. If several bushes grew in the vicinity of a plot, their indices were summed together. The variation among the plots for the bush effect index was $0-11$. As with the vegetation and soil values, these values were used as covariates in the statistical models. 


\section{Soil Sampling and Laboratory Measurements of Chemical and Biological Soil Properties}

To measure soil $\mathrm{C}$ and $\mathrm{N}$ concentrations and microbial biomass and activity, soil samples (diameter $2.5 \mathrm{~cm}$ ) were collected from three (or more if the soil was shallow) random spots under the field layer vegetation in each treatment plot in August 2018. To make sure all collected soil represented the original field soil, samples were collected between the planted birches and no soil under the birches was included. Each soil core was split into three layers: organic layer, $0-5 \mathrm{~cm}$ of mineral soil, and $>5 \mathrm{~cm}$ of mineral soil. The depth of the organic layer and mineral soil was recorded for each core. Each plot contained sampled spots where mineral soil $>5 \mathrm{~cm}$ was not found, and the average depth of mineral soil was in some plots less than $5 \mathrm{~cm}$.

The samples from each layer were pooled for each plot and sieved through a $2-\mathrm{mm}$ (mineral soil) or $6-\mathrm{mm}$ (organic soil) mesh. Samples were kept at $6^{\circ} \mathrm{C}$ for less than a week before analyses. Sub-samples of sieved soil used for $\mathrm{C}$ and $\mathrm{N}$ concentration measurements were dried at $40^{\circ} \mathrm{C}$, ground and measured using a Vario Max $\mathrm{CN}$ analyser (Germany).

The quantity of microbial biomass carbon (MBC) was determined according to Vance et al. (1987). In brief, $3 \mathrm{~g}$ organic or $8 \mathrm{~g}$ mineral sieved field-moist soil was filled into two flasks per sample. One of the two flasks was used as a control. The controls were immediately extracted using $40 \mathrm{ml}$ of $0.05 \mathrm{M}$ $\mathrm{K}_{2} \mathrm{SO}_{4}$ solution. After shaking for $30 \mathrm{~min}$ the solution was filtered through a Whatman No. 42 filter and subsequently through a $0.45-\mu \mathrm{m}$ syringe filter (Sartorius, Minisart High Flow, PES). The other set of flasks were placed into a desiccator, equipped with three beakers containing $40 \mathrm{ml}$ of chloroform. The desiccator was set to vacuum to let the chloroform boil for $2 \mathrm{~min}$. Subsequently, the flasks were incubated for $22.5 \mathrm{~h}$ in the dark. Afterward, the soil was defumigated using vacuum and extracted as described for the control flasks. Concentrations of $\mathrm{C}$ in the extracts were measured using a Shimadzu TOC$\mathrm{V}$ cph/cpn analyser (Kyoto, Japan), and MBC was calculated as the difference between the fumigated and control samples after correcting for dry weight. Since the efficiency of soil microbial carbon extraction (Kec factor) varies widely between different soils (e.g., Sparling et al., 1990), we only report the $\mathrm{C}$ flush released by fumigation without applying a $\mathrm{Kec}$ factor (e.g., Bailey et al., 2002).

For quantifying the heterotrophic soil respiration in controlled conditions, $3 \mathrm{~g}$ (fresh mass) sieved organic soil and $15 \mathrm{~g}(0-5 \mathrm{~cm})$ and $20 \mathrm{~g}(>5 \mathrm{~cm})$ sieved mineral soil was filled into incubation flasks. The dry mass content of soil samples was $0.91 \pm 0.26 \mathrm{~g}$ (mean $\pm \mathrm{SD}$ ) in the organic layer, $11.5 \pm 2.1 \mathrm{~g}$ in the $0-5 \mathrm{~cm}$ layer, and $15.5 \pm 3.6 \mathrm{~g}$ in the $>5 \mathrm{~cm}$ layer. All samples were wetted to $60 \%$ water holding capacity. The flasks were closed with rubber septa and placed in an incubator at $15^{\circ} \mathrm{C}$. The $\mathrm{CO}_{2}$ concentration in the flask headspace was measured after 3.5, 75, and $100 \mathrm{~h}$ using a gas chromatograph (Hewlett Packard 6890). The hourly $\mathrm{CO}_{2}$ release was estimated from the slope of the regression line between time and the $\mathrm{CO}_{2}$ concentration, and was corrected for dry weight of the soil.

\section{Root Sampling and Measurement of Shoot Abundance}

To estimate treatment effects on the root biomass of the field layer vascular plants, two soil cores were collected from each plot between the planted birches in August 2020 using an auger (diameter $4.5 \mathrm{~cm}$ ). The auger was drilled into the soil as deep as possible, and soil was split into organic layer, $0-5 \mathrm{~cm}$ mineral soil, and $>5 \mathrm{~cm}$ mineral soil. However, as the mineral soil was not consistently deeper than $5 \mathrm{~cm}$, we chose to only present data for the organic layer and $0-5 \mathrm{~cm}$ mineral soil. Roots were carefully sieved, washed, and dried at $60^{\circ} \mathrm{C}$ and their biomass calculated as root biomass per soil volume for both soil layers separately.

Vascular plant shoot abundance was quantified in August 2020 using a point-intercept method with 50 vertical pins that were systematically placed on each plot. All the hits for each vascular plant species per pin were recorded. For this study, we summed up the hits of all vascular plant species to obtain a measure of total vascular plant shoot abundance in each plot. Using the estimates of total vascular shoot abundance (hits on 50 pins per $0.3 \mathrm{~m}^{2}$ ) and total root biomass in the organic and $0-5 \mathrm{~cm}$ mineral layer ( $\mathrm{g}$ dry mass per $0.3 \mathrm{~m}^{2}$ ) we further calculated a root-to-shoot allocation index ( $g$ root dry mass per number of shoot hits on 50 pins).

\section{In situ Mineral N Availability and Soil Respiration}

In the field, mineral $\mathrm{N}$ availability in the soil organic layer was measured using UNIBEST Ag Manager ${ }^{\mathrm{TM}}$ (Walla Walla, Washington, United States) ion-exchange resin capsules (Robertson et al., 1999). Three resin capsules were placed at $3 \mathrm{~cm}$ depth in each plot in July 2016. In the following autumns one (2017) or two (2018) capsules per plot were transferred to the laboratory for $\mathrm{NH}_{4}{ }^{+}$and $\mathrm{NO}_{3}{ }^{-}$extraction in $50 \mathrm{ml}$ of $2 \mathrm{M} \mathrm{KCl}$. The $\mathrm{KCl}$ solution was filtered through a glass microfiber filter (Whatman, Germany) and the concentrations of $\mathrm{NH}_{4}{ }^{+}$and $\mathrm{NO}_{3}{ }^{-}$were analysed using a Lachat Quikchem 8000 analyser (Zellweger Analytics, Lachat Instruments Division, United States).

Soil respiration was measured four times during the growing season 2017 and four times during the growing season 2018 by pressing a chamber (inner diameter $28 \mathrm{~mm}$ ) attached to a Vaisala GMP252 probe (Vaisala Oyj, Finland) tightly against the soil surface under the field layer vegetation between the planted birches (three random spots in each plot). Any loose plant litter was moved aside for the duration of the measurement. Soil respiration, when measured from the soil surface in the field, represents the sum of the heterotrophic soil respiration and autotrophic root respiration. After closing the chamber, the $\mathrm{CO}_{2}$ concentration (ppm) was allowed to settle for $1 \mathrm{~min}$ and was then recorded for $1.5 \mathrm{~min}$. The $\mathrm{CO}_{2}$ accumulation rate $\left(\mathrm{ppm} \mathrm{min}{ }^{-1}\right)$ was calculated using a linear part of the recorded data and the $\mathrm{CO}_{2}$ efflux $\mathrm{F}$ was calculated as:

$F\left(g C \mathrm{CO}_{2} \mathrm{~m}^{-2} \mathrm{~s}^{-1}\right)=\frac{d C}{d t} \times \frac{P}{R T} \times \frac{V}{A} \times \frac{10^{-6}}{60} \times 44.01 \frac{\mathrm{g}}{\mathrm{mol}}$

where $\frac{d C}{d t}$ is the change in $\mathrm{CO}_{2}$ concentration in time (ppm $\left.\min ^{-1}\right), P$ is atmospheric pressure (101 $\left.235 \mathrm{~Pa}\right), R$ is the gas 
constant $\left(8.314 \mathrm{~J} \mathrm{~mol}^{-1} \mathrm{~K}^{-1}\right), T$ is temperature $(\mathrm{K}), V$ is the total free air space within the chamber $\left(1.9878 \times 10^{-5} \mathrm{~m}^{3}\right)$ and $A$ is the chamber area $\left(6.1575 \times 10^{-4} \mathrm{~m}^{2}\right)$. The efflux rate was calculated individually for each measurement, but later means were calculated of the three within-plot measurements to be used as replicates in the statistical analysis. We acknowledge that with our small chamber (28 mm diameter), the flux measurements are only a rough estimate for the entire plot. Yet, with this approach we were able to focus on natural soils beneath the natural field layer vegetation not disturbed by birch planting.

\section{Statistics}

The main and interaction effects of treatments on response variables were tested using linear mixed models and Type I ANOVA (IBM SPSS Statistics 21), where the variance is allocated to explanatory variables in order of their appearance in the model. SOM content, nutrient concentrations, bush effect index and the areal cover of vascular plants, lichens and mosses were treated as covariates and included in appropriate models before treatments to remove plot-to-plot variation that might otherwise contribute to treatment effects. Non-significant covariates were left out from final models. The warming and herbivory reduction treatments were treated as fixed effects and field block as a random effect. Measurement date and soil layer were treated as repeated measurements and compound symmetry was used as repeated covariance structure. The ANOVA assumption of normal distribution was checked using histograms and ShapiroWilk tests of model residuals. If residuals were not normally distributed, the data was square root- or log-transformed, the choice between these depending on the skewness of the distribution (transformations are reported in Figure legends).

\section{RESULTS}

\section{Vascular Plant Shoot and Root Abundance}

Warming and herbivory reduction increased the total shoot abundance of field layer vascular plants on average by 33 and 24\%, respectively (Figure 1A; Table 1). Total root dry mass was on average $38 \mathrm{mg} \mathrm{cm}{ }^{-3}$ soil in the organic layer and $7 \mathrm{mg} \mathrm{cm}{ }^{-3}$ soil in the upper mineral layer and was affected by a warming $\times$ herbivory reduction interaction (Figure 1B; Table 2). When applied alone, warming and herbivory reduction, respectively, increased root mass by 32 and $42 \%$ in the soil organic layer and 138 and $280 \%$ in the upper mineral soil (Figure 1B). However, when the treatments were applied together, the root mass did not differ from root mass found in plots with warming only, and was on average 30\% lower than root mass in plots with reduced herbivory only (Figure 1B). Warming decreased root-to-shoot allocation on average by $41 \%$, while herbivory reduction had no effect (Figure 1C; Table 1).

\section{Soil $\mathbf{C}$ and N Concentrations}

Soil C concentrations were on average $41,1.7$, and $0.8 \%$, and soil $\mathrm{N}$ concentrations $1.6,0.14$, and $0.12 \%$, in the organic, $0-5 \mathrm{~cm}$ mineral and $>5 \mathrm{~cm}$ mineral soil layers, respectively, and both were significantly affected by a warming $\times$ herbivory reduction interaction (Figure 2; Table 3). These interaction effects arise because warming and herbivory reduction increased soil $\mathrm{C}$ and $\mathrm{N}$ concentrations when applied alone, but not when combined (Figure 2). Moreover, as suggested by the significant herbivory reduction $\times$ soil layer interaction effect on $\mathrm{C}$ concentration (Table 3), herbivory reduction had a bigger relative impact on soil $\mathrm{C}$ concentration in the $0-5 \mathrm{~cm}$ mineral layer ( $91 \%$ increase) and the $>5 \mathrm{~cm}$ mineral layer (79\% increase) than in the organic layer (4\% increase) in plots with ambient temperature (Figure 2). On the other hand, the definite increase of $\mathrm{C}$ concentration in the organic layer (1.63\%-unit) was bigger than the increase in the $0-5 \mathrm{~cm}$ mineral layer $(1.16 \%$-unit) and $>5 \mathrm{~cm}$ mineral layer (0.52\%-unit) (Figure 2).

Warming increased soil $\mathrm{C}$ concentration in the organic layer by $9 \%$, in the $0-5 \mathrm{~cm}$ mineral layer by $16 \%$ and had no effect in the $>5 \mathrm{~cm}$ mineral layer in plots with natural herbivory (Figure 2). Soil $\mathrm{N}$ concentration was increased by warming and herbivory reduction on average by 16 and $18 \%$, respectively, in plots with no other treatment (Figure 2).

Soil C:N ratio decreased with increasing depth, being on average 26,12 , and 6.4 in the organic, $0-5 \mathrm{~cm}$ mineral and $>5 \mathrm{~cm}$ mineral soil layers, respectively (Figure 2). In contrast to $\mathrm{C}$ and $\mathrm{N}$ concentrations, no statistically significant warming $\times$ herbivory reduction interaction effect on soil C:N ratio was found (Table 3 ). Instead, warming decreased the $\mathrm{C}: \mathrm{N}$ ratio on average by $8 \%$ across all treatment combinations and soil layers (Figure 2; Table 3). The herbivory reduction effect followed the effect on $\mathrm{C}$ concentration in that it varied across the soil layers (Table 3 ): the C:N ratio was increased by herbivory reduction on average by $25 \%$ in mineral soil and decreased on average by $5.7 \%$ in the organic layer (Figure 2).

\section{Soil Microbial Biomass $\mathbf{C}$ and Respiration}

The amount of microbial biomass carbon (MBC, quantified as $\mathrm{C}$ released by fumigation) was on average 37 -fold in the organic layer in comparison to the mineral soil (Figure 3). A significant warming $\times$ herbivory reduction effect on $\mathrm{MBC}$ was found (Table 4). This was because warming and herbivory reduction increased $\mathrm{MBC}$ on average by 15 and $10 \%$, respectively, when applied alone, but not when combined (Figure 3). The significant herbivory reduction $\times$ soil layer interaction effect on MBC (Table 4) is in turn explainable by a considerable herbivory reduction effect in 0-5 (61\% increase) and $>5 \mathrm{~cm}$ (70\% increase) mineral soil layers and a modest effect in the organic layer $(3 \%$ decrease) (Figure 3).

Soil respiration measured in the laboratory under standardized conditions of temperature and moisture and with plant roots removed revealed a significant warming $\times$ herbivory reduction $\times$ soil layer interaction effect (Table 4). This interaction was because warming and herbivory reduction increased soil respiration on average by 25 and $22 \%$, respectively, when applied alone but not when combined in the organic and $0-5$ mineral soil layers, whereas in the $>5 \mathrm{~cm}$ mineral layer no effects were found (Figure 3). On average, the respiration was 70 -fold in the organic layer in comparison to the mineral soil 


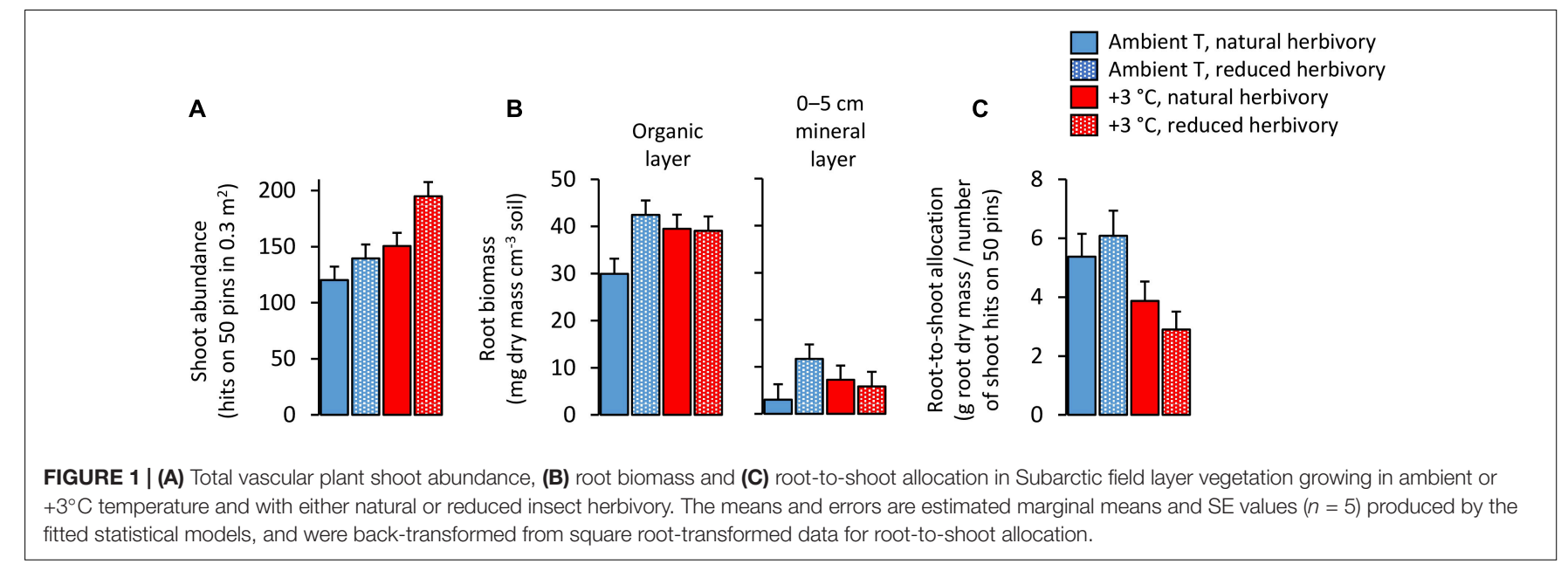

TABLE 1 | $F$ and $P$ statistics of the effects of warming (ambient, $+3^{\circ} \mathrm{C}$ ), herbivory reduction (normal, reduced) and initial vascular plant cover on the total shoot abundance and root-to-shoot allocation of field layer vascular plants (block was included in the model as a random factor and the initial soil $\mathrm{NH}_{4}{ }^{+}$concentration as an additional covariate, but these effects are not reported; $P<0.05$ are in bold).

\begin{tabular}{lccccccc}
\hline & \multicolumn{3}{c}{ Shoot abundance } & \multicolumn{3}{c}{ Root-to-shoot allocation } \\
\cline { 2 - 8 } & df & $\boldsymbol{F}$ & $\boldsymbol{P}$ & df & $\boldsymbol{F}$ & $\boldsymbol{P}$ \\
\hline Initial vascular plant cover & 1,14 & 10.8 & $\mathbf{0 . 0 0 5}$ & 1,14 & 1.14 & 0.303 \\
Warming (W) & 1,14 & 10.5 & $\mathbf{0 . 0 0 6}$ & 1,14 & 9.90 & $\mathbf{0 . 0 0 7}$ \\
Herbivory reduction (HR) & 1,14 & 7.16 & $\mathbf{0 . 0 1 8}$ & $\mathbf{1 , 1 4}$ & 0.13 & 0.726 \\
W $\times$ HR & 1,14 & 1.01 & 0.332 & 1,14 & 1.50 & 0.241 \\
\hline
\end{tabular}

(Figure 3). The specific soil respiration (ratio of respiration to soil C content) was also affected by a significant warming $\times$ herbivory reduction $\times$ soil layer interaction (Table 4 ), but for a different reason: in the organic layer, warming and herbivory reduction, respectively, increased the ratio on average by 15 and $12 \%$ when applied alone, but not when combined; in the $0-5$ mineral soil layer no effects were found; and in the $>5 \mathrm{~cm}$ mineral layer, herbivory reduction decreased the ratio on average by $44 \%$ when applied alone (Figure 3).

\section{In situ Soil Mineral N Availability and Respiration}

A significant warming $\times$ herbivory reduction effect was found on the amount of $\mathrm{NH}_{4}{ }^{+}$captured in resin capsules in the organic layer (Figure 4; Table 5). This interaction was because warming and herbivory reduction led to 16-fold and 11-fold $\mathrm{NH}_{4}{ }^{+}$capture, respectively, when applied alone, but not when combined (Figure 4). In contrast, the amount of $\mathrm{NO}_{3}{ }^{-}$captured was increased by warming on average by $79 \%$ in all treatment combinations and was not significantly affected by herbivory reduction (Figure 4; Table 5).

Warming had no statistically significant effect on soil respiration in either year, whereas herbivory reduction had a marginally significant positive effect in both years: respiration was on average $14 \%$ and $13 \%$ higher with reduced than normal
TABLE $2 \mid \mathrm{F}$ and $\mathrm{P}$ statistics of the effects of warming (ambient, $+3^{\circ} \mathrm{C}$ ), herbivory reduction (normal, reduced), soil layer (organic soil, $0-5 \mathrm{~cm}$ mineral soil, $>5 \mathrm{~cm}$ mineral soil) and initial vascular plant cover on total root mass of field layer vegetation (block was included in the models as a random factor, and moss cover, soil OM content and soil $\mathrm{PO}_{4}{ }^{3-}$ concentration as additional covariates, but these effects are not reported; $P<0.05$ are in bold).

\begin{tabular}{lccc}
\hline & \multicolumn{3}{c}{ Root mass } \\
\cline { 2 - 4 } & df & $\boldsymbol{F}$ & \multicolumn{1}{c}{$\boldsymbol{P}$} \\
\hline Initial vascular plant cover & 1,9 & 21.4 & $\mathbf{0 . 0 0 1}$ \\
Warming (W) & 1,8 & $<0.01$ & 0.938 \\
Herbivory reduction (HR) & 1,8 & 5.52 & $\mathbf{0 . 0 4 6}$ \\
Soil layer (SL) & 1,16 & 202 & $<\mathbf{0 . 0 0 1}$ \\
W $\times$ HR & 1,8 & 14.5 & $\mathbf{0 . 0 0 5}$ \\
W $\times$ SL & 1,16 & 0.81 & 0.381 \\
HR $\times$ SL & 1,16 & 0.31 & 0.585 \\
W $\times$ HR $\times$ SL & 1,16 & 0.12 & 0.738 \\
\hline
\end{tabular}

herbivory in 2017 and 2018, respectively (Figure 5; Table 6). No warming $\times$ herbivory reduction interaction effect appeared in either year (Figure 5; Table 6).

\section{DISCUSSION}

Earlier observations at our study plots have indicated that warming and insect herbivory reduction increase plant $\mathrm{CO}_{2}$ capture and growth (Silfver et al., 2020). We hypothesized that these effects would in turn increase soil $\mathrm{C}$ input and microbial biomass. Due to increased microbial $\mathrm{N}$ mining and associated priming of SOM decomposition, this would lead to lower soil $\mathrm{C}$ concentrations. In line with our hypothesis, both warming and reduced herbivory increased root growth, microbial biomass and activity, and $\mathrm{N}$ mineralization. However, contrary to our hypothesis, they increased rather than reduced soil $\mathrm{C}$ concentrations. These results indicate that the increasing $\mathrm{C}$ input from vegetation into Subarctic soil under climate warming may compensate for the accelerating decomposition of soil organic C. On the other hand, the 


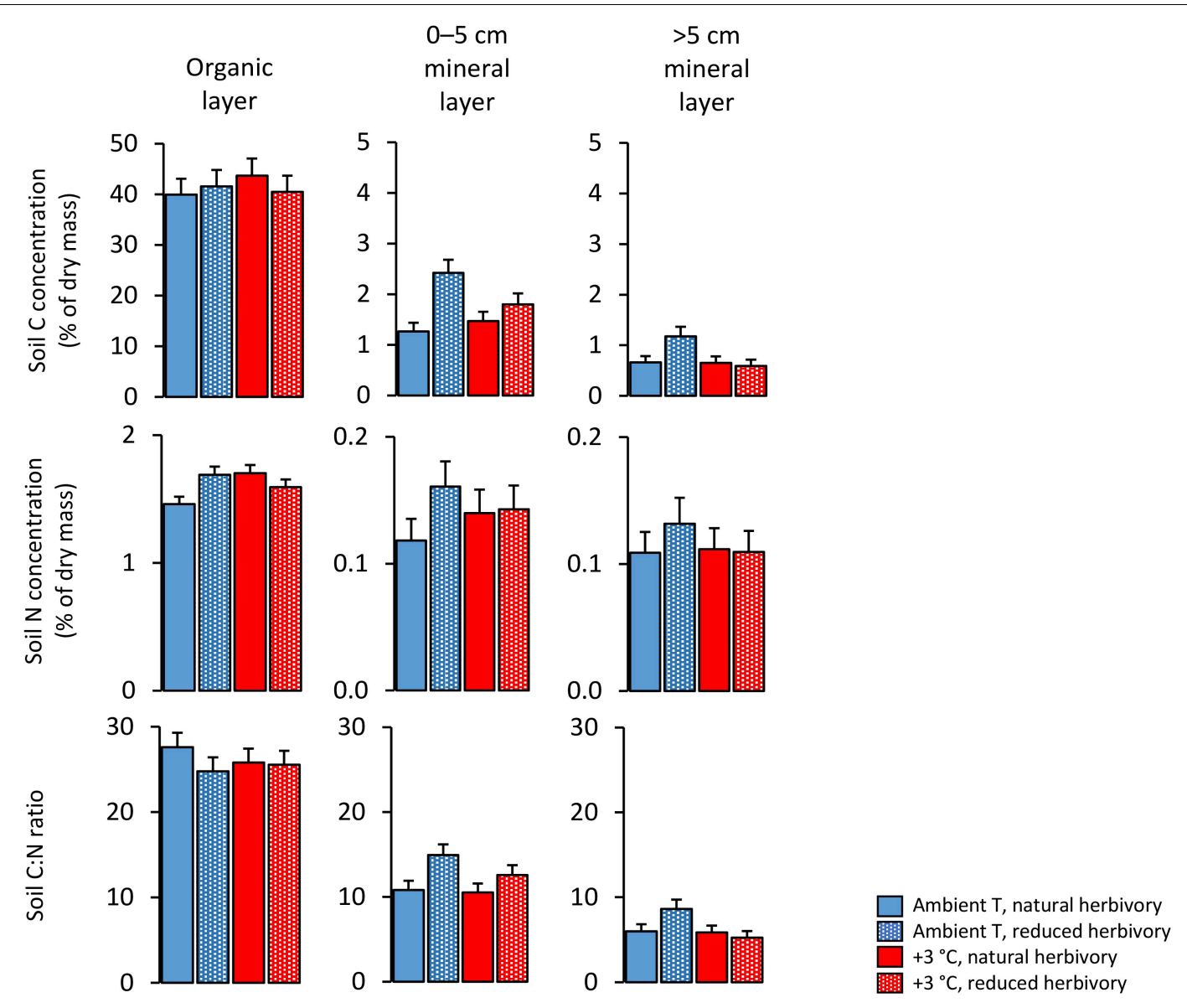

FIGURE 2 | C and N concentrations and C:N ratio of soil layers under Subarctic field layer vegetation growing in ambient or $+3^{\circ} \mathrm{C}$ temperature and with either natural or reduced insect herbivory. The mean and SE values are estimated marginal means and SE values $(n=5)$ produced by the fitted statistical models and were back-transformed from log-transformed data for $\mathrm{C}$ concentration and from square root-transformed data for $\mathrm{N}$ concentration and $\mathrm{C}: \mathrm{N}$ ratio.

TABLE 3 | F and P statistics of the effects of warming (ambient, $+3^{\circ} \mathrm{C}$ ), herbivory reduction (normal, reduced) and soil layer (organic soil, $0-5 \mathrm{~cm}$ mineral soil, $>5 \mathrm{~cm}$ mineral soil), on soil $\mathrm{C}$ and $\mathrm{N}$ concentrations and $\mathrm{C}: \mathrm{N}$ ratio under forest field layer vegetation (block was included in the models as a random factor and the initial soil $\mathrm{NH}_{4}{ }^{+}$concentration as a covariate, but these effects are not reported; $P<0.05$ are in bold).

\begin{tabular}{|c|c|c|c|c|c|c|c|c|c|}
\hline & \multicolumn{3}{|c|}{ C concentration } & \multicolumn{3}{|c|}{$\mathrm{N}$ concentration } & \multicolumn{3}{|c|}{ C:N ratio } \\
\hline & df & $\boldsymbol{F}$ & $\boldsymbol{P}$ & df & $\boldsymbol{F}$ & $\boldsymbol{P}$ & df & $\boldsymbol{F}$ & $P$ \\
\hline Warming (W) & 1,15 & 2.96 & 0.106 & 1,15 & 0.03 & 0.869 & 1,11 & 5.28 & 0.041 \\
\hline Herbivory reduction (HR) & 1,15 & 8.80 & 0.010 & 1,15 & 4.26 & 0.057 & 1,11 & 4.01 & 0.070 \\
\hline Soil layer (SL) & 2,31 & 3073 & $<0.001$ & 2,31 & 2398 & $<0.001$ & 2,32 & 273 & $<0.001$ \\
\hline $\mathrm{W} \times \mathrm{HR}$ & 1,15 & 8.33 & 0.011 & 1,15 & 8.59 & 0.011 & 1,12 & 2.16 & 0.168 \\
\hline$W \times S L$ & 2,31 & 2.23 & 0.125 & 2,31 & 1.10 & 0.347 & 2,32 & 0.76 & 0.474 \\
\hline $\mathrm{HR} \times \mathrm{SL}$ & 2,31 & 5.41 & 0.010 & 2,31 & 0.12 & 0.887 & 2,32 & 3.61 & 0.039 \\
\hline $\mathrm{W} \times \mathrm{HR} \times \mathrm{SL}$ & 2,31 & 0.74 & 0.487 & 2,31 & 1.51 & 0.237 & 2,32 & 1.91 & 0.165 \\
\hline
\end{tabular}

fact that reduced insect herbivory significantly increased the shoot and root growth of Subarctic vegetation and soil C concentrations suggests that increasing herbivore pressure with increasing temperature might significantly curtail the positive effect of enhanced plant growth on soil C. Moreover, our results show that temperature and herbivory effects on soil variables interact strongly, which may further complicate the effects of rising temperatures on soil C dynamics.

\section{Warming and Herbivory Effects on Soil C Dynamics}

We hypothesized that warming will increase soil $\mathrm{C}$ mineralisation through two mechanisms: first, the decomposition rate of 




FIGURE 3 | Microbial biomass C (MBC), laboratory-based soil respiration rate and ratio of soil respiration rate to unit soil C (specific soil respiration rate) in soil layers under Subarctic field layer vegetation growing in ambient or $+3^{\circ} \mathrm{C}$ temperature and with either natural or reduced insect herbivory. The means and errors are estimated marginal means and SE values $(n=5)$ produced by the fitted statistical models and were back-transformed from square root-transformed data except for the specific soil respiration rate, which did not need transformation for statistical analysis.

TABLE 4 | F and P statistics of the effects of soil layer (organic layer, 0-5 cm mineral soil, $>5 \mathrm{~cm}$ mineral soil), warming (ambient, $+3^{\circ} \mathrm{C}$ ) and herbivory reduction (normal, reduced) on microbial biomass $\mathrm{C}(\mathrm{MBC}$ ), lab-based soil respiration and specific soil respiration rate (soil respiration per unit SOC) under field layer vegetation (block was included in the models as a random factor and moss cover as a covariate for soil respiration and soil respiration/SOC, but these effects are not reported; $P<0.05$ are in bold).

\begin{tabular}{|c|c|c|c|c|c|c|c|c|c|}
\hline & \multicolumn{3}{|c|}{ MBC } & \multicolumn{3}{|c|}{ Soil respiration } & \multicolumn{3}{|c|}{ Specific soil respiration rate } \\
\hline & df & $\boldsymbol{F}$ & $P$ & df & $\boldsymbol{F}$ & $P$ & df & $\boldsymbol{F}$ & $P$ \\
\hline Warming (W) & 1,12 & 0.31 & 0.589 & 1,14 & $<0.01$ & 0.945 & 1,15 & 0.44 & 0.517 \\
\hline Herbivory reduction (HR) & 1,12 & 4.56 & 0.054 & 1,15 & 0.02 & 0.905 & 1,15 & 0.49 & 0.497 \\
\hline Soil layer (SL) & 2,32 & 3972 & $<0.001$ & 2,31 & 959 & $<0.001$ & 1,32 & 55.8 & $<0.001$ \\
\hline$W \times H R$ & 1,12 & 19.8 & 0.001 & 1,15 & 4.23 & 0.058 & 1,15 & 0.03 & 0.858 \\
\hline $\mathrm{W} \times \mathrm{SL}$ & 2,32 & 1.06 & 0.360 & 2,31 & 0.03 & 0.976 & 2,32 & 0.46 & 0.634 \\
\hline $\mathrm{HR} \times \mathrm{SL}$ & 2,32 & 4.38 & 0.021 & 2,31 & 0.44 & 0.648 & 2,32 & 0.02 & 0.980 \\
\hline $\mathrm{W} \times \mathrm{HR} \times \mathrm{SL}$ & 2,32 & 0.29 & 0.752 & 2,31 & 3.51 & 0.042 & 2,32 & 3.70 & 0.036 \\
\hline
\end{tabular}

SOM will be higher in higher temperatures (Lloyd and Taylor, 1994; Kirschbaum, 1995) and second, the increased plant growth and associated root $\mathrm{C}$ release will cause priming of SOM (Kuzyakov et al., 2000; Fontaine et al., 2004). This would ultimately induce soil $\mathrm{C}$ losses if the accelerated soil $\mathrm{C}$ mineralization is not compensated by soil $\mathrm{C}$ accrual through 


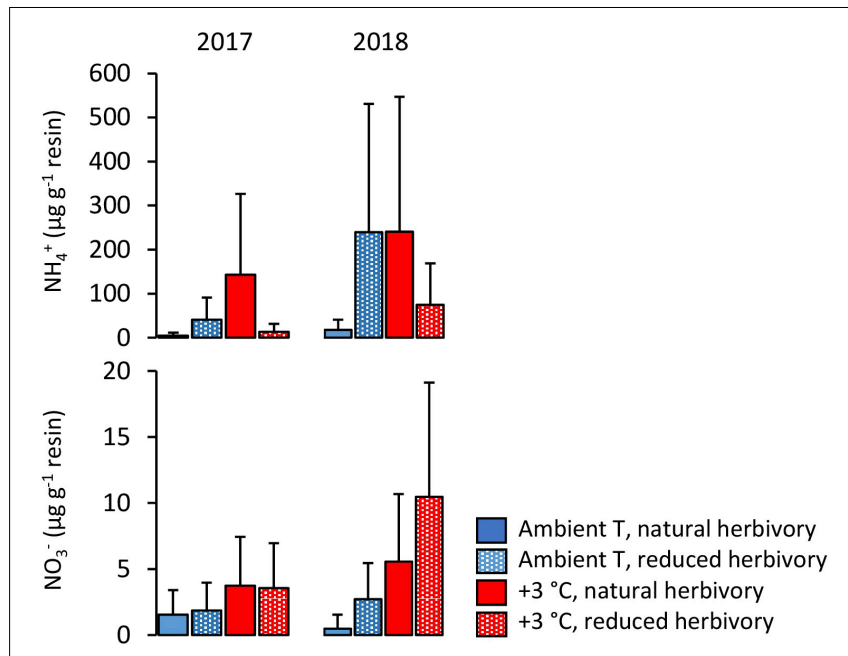

FIGURE 4 | $\mathrm{NH}_{4}{ }^{+}$and $\mathrm{NO}_{3}{ }^{-}$contents of resin bags incubated for one (2017) or two (2018) full growing seasons under Subarctic field layer vegetation growing in ambient or $+3^{\circ} \mathrm{C}$ temperature and with either natural or reduced insect herbivory. The means and errors are estimated marginal means and SE values $(n=5)$ produced by the fitted statistical models and were back-transformed from log-transformed data.

increasing plant litter production (Hagedorn et al., 2010). We found 9-16\% higher $C$ concentrations with warming in the organic layer and in the upper $5 \mathrm{~cm}$ of mineral soil in plots with natural herbivory. Most likely, this was a consequence of increased root growth and litter production in these plots. Our results thus confirm the earlier observation of increasing organic layer C under Subarctic shrub vegetation in response to warming (Ylänne et al., 2015) and contradict the suggestions that accelerated decomposition with warming (Marañón-Jiménez et al., 2019) and intensifying priming effect with greater plant growth (Hartley et al., 2012; Parker et al., 2015; Friggens et al., 2020b) would lead to soil C losses.

Although warming did not increase leaf damages in our experiment (Silfver et al., 2020), Arctic warming is supposed to come along with higher insect herbivore pressure (Kozlov, 2008; Wolf et al., 2008; Currano et al., 2010; Kozlov et al., 2015). Our results show that already the current herbivore pressure can substantially reduce vascular plant shoot and root growth. This is in line with a recent meta-analysis, which showed that insect herbivory reduces woody plant root biomass and thereby the input of C into the soil (Kristensen et al., 2020). It is likely that these negative effects on plant growth will intensify in a linear manner (Zvereva et al., 2012) if the abundance of insects increase with warming as suggested. Our results also show that these effects can further propagate into effects on soil $\mathrm{C}$ concentrations: the reduced herbivory increased the $\mathrm{C}$ concentrations in all soil horizons, but especially in the mineral soil. This effect is likely a result of increased root growth. Remarkably, these results suggest that the aboveground insect herbivory, through affecting plant root growth, may affect the distribution of $\mathrm{C}$ in the soil.

We acknowledge that we are operating with changes in soil $\mathrm{C}$ and $\mathrm{N}$ concentrations, which may not have one-to-one
TABLE 5 | F and $\mathrm{P}$ statistics of the effects of warming (ambient, $+3^{\circ} \mathrm{C}$ ) and herbivory reduction (normal, reduced) on the quantity of $\mathrm{NH}_{4}{ }^{+}$and $\mathrm{NO}_{3}{ }^{-}$ captured by resin capsules placed under field layer vegetation and harvested after one and two growing seasons (block was included in the models as a random factor and the initial soil $\mathrm{NH}_{4}{ }^{+}$and $\mathrm{NO}_{3}{ }^{-}$concentrations as covariates, but these effects are not reported; $P<0.05$ are in bold).

\begin{tabular}{|c|c|c|c|c|c|c|}
\hline & \multicolumn{3}{|c|}{$\mathrm{NH}_{4}{ }^{+}$} & \multicolumn{3}{|c|}{$\mathrm{NO}_{3}{ }^{-}$} \\
\hline & df & $\boldsymbol{F}$ & $\boldsymbol{P}$ & df & $F$ & $P$ \\
\hline Warming $(\mathrm{W})$ & 1,10 & 3.83 & 0.078 & 1,14 & 5.50 & 0.034 \\
\hline Herbivory reduction (HR) & 1,10 & 1.29 & 0.281 & 1,14 & 0.94 & 0.349 \\
\hline Harvest year $(\mathrm{HY})$ & 1,16 & 7.11 & 0.017 & 1,16 & 0.40 & 0.534 \\
\hline$W \times H R$ & 1,10 & 17.0 & 0.002 & 1,14 & 0.09 & 0.771 \\
\hline $\mathrm{W} \times \mathrm{HY}$ & 1,16 & 0.17 & 0.687 & 1,16 & 1.07 & 0.316 \\
\hline $\mathrm{HR} \times \mathrm{HY}$ & 1,16 & 0.77 & 0.392 & 1,16 & 0.90 & 0.357 \\
\hline $\mathrm{W} \times \mathrm{HR} \times \mathrm{HY}$ & 1,16 & 0.09 & 0.767 & 1,16 & 0.02 & 0.888 \\
\hline
\end{tabular}

relationships with changes in soil $\mathrm{C}$ and $\mathrm{N}$ stocks. The reason for choosing concentrations rather than stocks is that reliably estimating treatment effects on stocks would be notoriously difficult at a field site, where the depth of soil layers and their bulk densities vary among and within treatment plots. These problems are also recognized in literature, where detecting changes in soil C stocks is considered particularly prone to uncertainties (Mäkipää et al., 2008; Schrumpf et al., 2011; Poeplau et al., 2017) and only considerable differences are thought to be detectable (Schrumpf et al., 2011). Accurate measurements of C stocks are further complicated by rocks (Poeplau et al., 2017), which are abundant at our study site. Therefore, in light of the comparatively short time scale considered here, we consider results on stock changes unreliable, and withhold from assessing them. However, as Heikkinen et al. (2013) demonstrated, changes in soil C and N concentrations can, at least in mineral soil, be used to indicate long-term trends in soil $\mathrm{C}$ and $\mathrm{N}$ stocks. We thus suggest that our results of increasing soil $\mathrm{C}$ concentrations in response to warming and herbivory reduction will also go along with higher $\mathrm{C}$ stocks at least in mineral soil.

While changes in soil $\mathrm{C}$ stocks are difficult to detect, changes in microbial biomass carbon (MBC) should provide a more sensitive indicator of $\mathrm{C}$ accumulation, or loss, since microbes swiftly respond to changes in environmental conditions and resource availability (Powlson et al., 1987). In our study, we found that changes in soil $\mathrm{C}$ concentrations were echoed in $\mathrm{MBC}$, and the $\mathrm{MBC}$ was significantly increased by warming and herbivory reduction where the treatments were not combined. The increase in $\mathrm{MBC}$ was relatively larger in the upper mineral soil than in the organic layer, especially in the case of the herbivory reduction effect. This may be one reason for the increasing $\mathrm{C}$ concentration that we found along with reduced herbivory in mineral soil as the recently proposed paradigm suggests that large parts of soil $\mathrm{C}$ consist of microbial necromass (Simpson et al., 2007; Fan and Liang, 2015). The finding that treatment effects on soil and microbial $\mathrm{C}$ dynamics were relatively stronger in the mineral soil is also in line with Sistla et al. (2013), who suggested "biotic awakening at depth" under warming. Altogether our results indicate that the effects of changes in plant growth on 

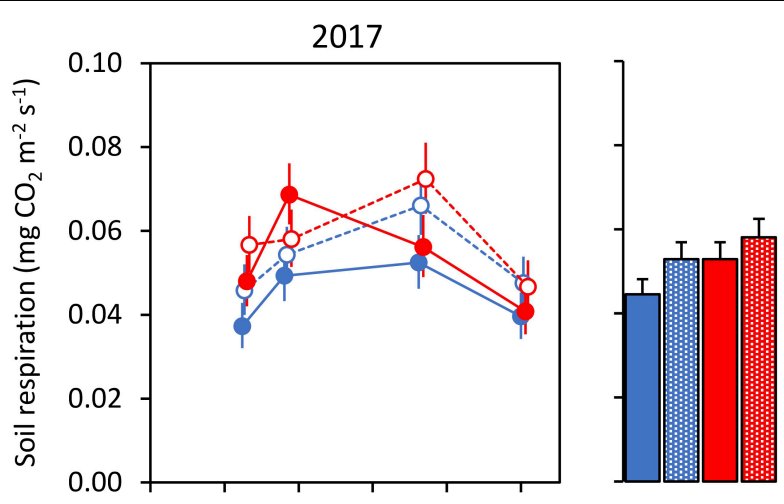

8.6. 29.6. 20.7. 10.8. 31.8. 21.9.
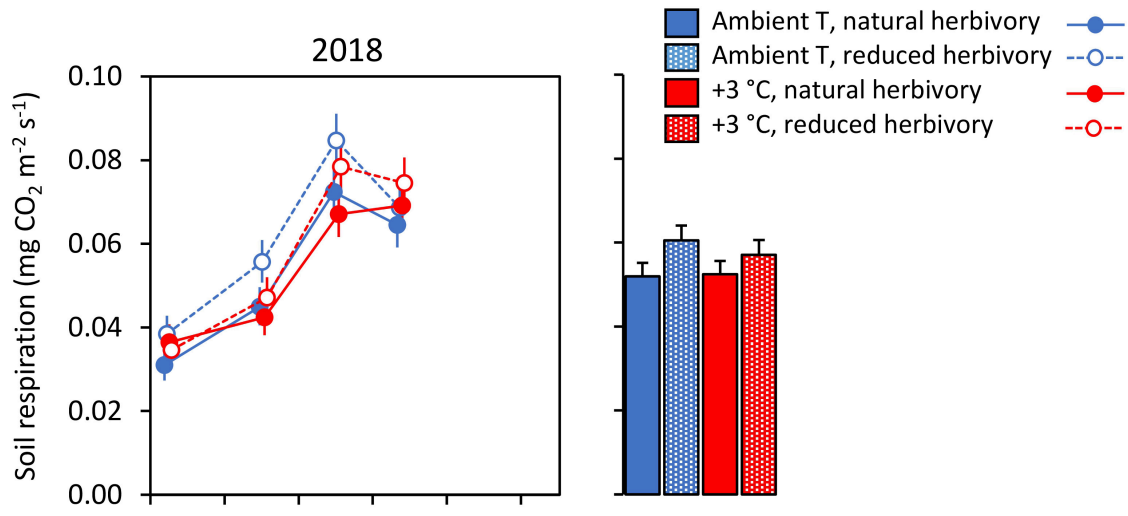

8.6. 29.6. 20.7. 10.8. 31.8. 21.9.

FIGURE 5 | In situ soil respiration under Subarctic field layer vegetation growing in ambient or $+3^{\circ} \mathrm{C}$ temperature and with either natural or reduced insect herbivory in 2017 and 2018 with seasonal means on right hand panels. The means and errors are estimated marginal means and SE values $(n=5)$ produced by fitted statistical models and were back-transformed from square root-transformed data.

soil $\mathrm{C}$ accumulation, either due to changes in insect herbivory or warming, may particularly take place in the upper mineral soil.

Considering that both the heterotrophic (Kirschbaum, 1995) and autotrophic (Atkin et al., 2000) respiration are sensitive to temperature and that warming increased root growth, microbial biomass and soil C concentrations, it was unexpected that the in situ soil respiration had only a non-significant, modest elevation in 2017 (i.e., after 1 year of warming) and did not increase at all with warming in 2018 (i.e., after 2 years of warming). These results suggest that the in situ soil respiration may not reveal the major changes that take place in soil biological activity and $\mathrm{C}$ concentrations under warming. In contrast, the positive effect of reduced herbivory on root growth and microbial activity was also echoed in soil respiration. Once again, this emphasizes the remarkable role of the seemingly low background insect herbivory in affecting $\mathrm{C}$ dynamics in Subarctic ecosystems.

\section{SOC Degradability as a Driver of Soil C Dynamics}

Warming has been reported not only to change the amount of soil $\mathrm{C}$, but also its degradability as the amount of labile and easily available $\mathrm{C}$ increases upon warming (Belay-Tedla et al., 2009; Zhang et al., 2010). This process can be due to an increase in plant and root residues, which are considered to be part of the labile pool (Janzen et al., 1992; Franzluebbers and Arshad, 1997), or due to a higher temperature response of recalcitrant C compounds (Conant et al., 2008; Lefèvre et al., 2014). On the other hand, some studies point to a depletion of labile soil $\mathrm{C}$ pools with warming ( $\mathrm{Xu}$ et al., 2012). Our results show that microbial respiration, when measured in standardized laboratory conditions of temperature and moisture, closely followed the warming-induced change in soil $\mathrm{C}$ concentration. This is a sign of microbial activity responding to resource quantity. However, when we calculated specific soil respiration rate (respiration rate per mass unit of soil C) as a proxy of soil C degradability (Rousk and Frey, 2015), we also found a higher specific rate in soils collected from warmed plots (under natural herbivory) than in soils collected from control plots. This points to a larger proportion of $\mathrm{C}$ being easily mineralizable in warmed plots.

Earlier studies have also reported better $\mathrm{C}$ availability under plants with insect herbivory, as insect frass returns easily available and nutrient rich organic matter to soil (Kaukonen et al., 2013; Kristensen et al., 2018). In our study, this would lead to lower specific soil respiration rate under reduced herbivory, especially in the organic layer. However, we found similar $(0-5 \mathrm{~cm}$ mineral soil) or higher (organic layer) specific soil respiration in plots with reduced herbivory. A likely reason is that the stimulated 
TABLE 6 | F and $P$ statistics of the effects of warming (ambient, $+3^{\circ} \mathrm{C}$ ), herbivory reduction (normal, reduced) and initial vascular plant cover on soil respiration in field plots during 2017 and 2018 growing seasons (block was included in the model as a random factor, but is not reported; $P<0.05$ are in bold).

\begin{tabular}{|c|c|c|c|c|c|c|}
\hline & \multicolumn{3}{|c|}{2017} & \multicolumn{3}{|c|}{2018} \\
\hline & df & $\boldsymbol{F}$ & $P$ & df & $\boldsymbol{F}$ & $\boldsymbol{P}$ \\
\hline Initial vascular plant cover & 1,16 & 13.3 & 0.002 & 1,15 & 15.2 & 0.001 \\
\hline Warming (W) & 1,16 & 2.25 & 0.154 & 1,15 & 0.17 & 0.689 \\
\hline Herbivory reduction (HR) & 1,15 & 3.07 & 0.100 & 1,15 & 4.09 & 0.061 \\
\hline Measurement date (MD) & 3,47 & 8.38 & $<0.001$ & 3,48 & 73.2 & $<0.001$ \\
\hline$W \times H R$ & 1,15 & 0.30 & 0.592 & 1,15 & 0.39 & 0.542 \\
\hline $\mathrm{W} \times \mathrm{MD}$ & 3,47 & 0.84 & 0.480 & 3,48 & 1.26 & 0.298 \\
\hline $\mathrm{HR} \times \mathrm{MD}$ & 3,47 & 1.29 & 0.290 & 3,48 & 0.51 & 0.676 \\
\hline$W \times H R \times M D$ & 3,47 & 0.37 & 0.775 & 3,48 & 0.40 & 0.751 \\
\hline
\end{tabular}

plant shoot and root growth with reduced herbivory brought labile $\mathrm{C}$ into the soil. This interpretation is further supported by the larger microbial biomass that we found under reduced herbivory. Most likely, the background insect herbivory is so low (Silfver et al., 2020) that frass production has a negligible role in $\mathrm{C}$ cycling. All in all, our results suggest that warming and insect herbivory affect not only the concentration of soil C, but also its mineralization rate.

\section{Warming and Herbivory Effects on Soil N Dynamics}

In addition to changes in soil $\mathrm{C}$ dynamics, we also found considerable changes in soil $\mathrm{N}$ dynamics along with our treatments. In such strongly $\mathrm{N}$ limited systems like the Arctic (Hobbie and Chapin, 1998), enhanced primary production and root exudation likely invoke $\mathrm{N}$ deficiency in plants, and ultimately also in soil microbes, whose $\mathrm{N}$ demand increases when roots bring easily available $\mathrm{C}$ into the soil (Dijkstra et al., 2013; Chen et al., 2014; Murphy et al., 2015). In our study, the resin capsule $\mathrm{N}$ contents in control plots show that there was basically no free mineral $\mathrm{N}$ available in the soil. In such conditions, microbial demand for $\mathrm{N}$ stimulates production of exoenzymes for the breakdown of $\mathrm{N}$ rich organic matter, leading to microbial N mining (Moorhead and Sinsabaugh, 2006; Craine et al., 2007) and accelerated mineralization of N. Supporting this line of argument, we found greater $\mathrm{NH}_{4}{ }^{+}$production with enhanced primary production in plots with higher temperature and reduced herbivory, but not in plots where the treatments were combined. What tells of better environmental conditions for bacteria in warmed plots in general is that warming led to an average $79 \%$ increase in resin $\mathrm{NO}_{3}{ }^{-}$capture over all treatment combinations. This shows that at least the nitrifying bacteria also directly benefited from warming.

Treatment effects on soil and microbial $\mathrm{N}$ followed closely the effects on soil and microbial C: i.e., warming and herbivory reduction (when applied alone) increased soil $\mathrm{N}$ concentration. It seems that with both warming and reduced herbivory, more of the organic $\mathrm{N}$ was mineralized and bound to plant biomass, as supported by larger resin $\mathrm{NH}_{4}{ }^{+}$and $\mathrm{NO}_{3}{ }^{-}$contents, root biomass, and shoot abundance. However, as in the case of mineral soil C concentrations, reduced herbivory increased $\mathrm{N}$ concentrations especially in the mineral soil. This shows how insect herbivory also has a control on the distribution of $\mathrm{N}$ in Subarctic soils, with the higher herbivore pressure increasing accumulation of $\mathrm{N}$ in the organic layer. The higher mineralization rate of $\mathrm{N}$ in warmed plots was also visible in plant resource allocation. Sufficient nutrient supply should lead to relatively higher biomass allocation aboveground than belowground (Gedroc et al., 1996), and indeed we observed significantly lower root-to-shoot ratios with warming. It also appears that there was less need for plants to extend their root growth to the mineral soil to search for $\mathrm{N}$ in warmed plots, as demonstrated by increases in root biomass especially in the organic layer. This is in line with the earlier observations that warming shifts the rooting zone toward the upper soil organic layer (Björk et al., 2007).

When reduced herbivory stimulates plant growth and thereby $\mathrm{CO}_{2}$ uptake in $\mathrm{N}$ poor environment as in our experiment (Silfver et al., 2020), it likely evokes plant $\mathrm{N}$ deficiency. A logical response by plants then is to grow roots deeper into the soil to search for N. Supporting this reasoning, we found the largest root biomass in mineral soil in plots with reduced herbivory and ambient temperature. The higher C:N ratio of the mineral soil with reduced herbivory further supports the idea that root growth and production of new SOM with higher C:N ratio increased in mineral soil with reduced herbivory. Intriguingly, we observed increasing soil $\mathrm{N}$ concentrations with herbivory reduction under ambient temperature. A possible explanation for this is that the increased root growth deeper into the soil brought $\mathrm{N}$, via decomposition of plant parts that acquired the $\mathrm{N}$, from deeper soil to the upper layers of the soil. This apparently provides a mechanism through which insect herbivory is able to control the distribution of $\mathrm{N}$ in Subarctic soils.

\section{Why So Few Additive Effects?}

One particular feature of our findings is that while we found strong effects of warming and herbivory reduction on soil and microbial variables, most of these effects were not additive. Significant warming $\times$ herbivory reduction interaction effects appeared on root biomass, soil $\mathrm{C}$ and $\mathrm{N}$ concentrations, MBC and $\mathrm{NH}_{4}$ availability and all these results seem to suggest that the treatments in most part canceled out each other's effects. These results are in stark contrast to the additive positive effects of warming and herbivory reduction on shoot abundance in our study and on birch plantlet height growth earlier observed in the same experiment (Silfver et al., 2020). Our explanation for this discrepancy is that while plant shoot growth directly profits from both warming and herbivory reduction, root and soil responses are a product of several interacting mechanisms, and are affected by the interdependence of soil $\mathrm{C}$ and $\mathrm{N}$ dynamics.

For instance, it appears that most of the effects of herbivory reduction on soil variables in our study can be explained by greater root growth for $\mathrm{N}$ acquisition. However, as warming increased mineral $\mathrm{N}$ availability, root growth was not induced by herbivory reduction in warmed plots. Moreover, in warmed plots with reduced herbivory, more of the additional mineral $\mathrm{N}$ 
probably became fastened to plant biomass, while less remained in the soil. Therefore, many responses of soil variables to the combination of warming and herbivory reduction did not exceed, or even achieve, the responses to warming and herbivory reduction alone. Considering the future warmer climate with presumably higher insect herbivore pressure (Kozlov, 2008; Wolf et al., 2008; Currano et al., 2010; Kozlov et al., 2015), our results suggest that $\mathrm{N}$ availability may increase relatively more (due to a positive warming effect) than plant $\mathrm{N}$ demand (due to a negative herbivory effect dampening the positive warming effect on plant growth). This might not induce higher $\mathrm{C}$ input and microbial activity in deeper soil layers as is often predicted (Sistla et al., 2013; Jia et al., 2019). Remarkably, our results suggest that vascular plant search for $\mathrm{N}$ is closely tied with soil $\mathrm{C}$ dynamics, and can at least partly explain why warming and herbivory reduction effects on soil $\mathrm{C}$ accumulation may not be additive.

\section{CONCLUSION}

Our study draws attention to the multiple interacting mechanisms behind warming effects on soil $\mathrm{C}$ dynamics in Subarctic areas, consisting of changes in primary production, microbial growth, $\mathrm{N}$ mineralization, plant $\mathrm{N}$ acquisition and plant root distribution among soil layers. Together, these mechanisms can apparently create nonlinear and unexpected responses to changes in temperature and herbivore pressure. This calls for careful consideration when predicting the fate of Subarctic C sink under climate warming.

\section{DATA AVAILABILITY STATEMENT}

The data presented in the study are deposited in the Dryad repository: Meyer et al. (2021).

\section{REFERENCES}

Atkin, O. K., Edwards, E. J., and Loveys, B. R. (2000). Response of root respiration to changes in temperature and its relevance to global warming. New Phytol. 147, 141-154. doi: 10.1093/aobpla/plz064

Bailey, V. L., Peacock, A. D., Smith, J. L., and Bolton, H. (2002). Relationships between soil microbial biomass determined by chloroform fumigationextraction, substrate-induced respiration, and phospholipid fatty acid analysis. Soil Biol. Biochem. 34, 1385-1389. doi: 10.1016/s0038-0717(02)00070-6

Beck, P. S. A., and Goetz, S. J. (2011). Satellite observations of high northern latitude vegetation productivity changes between 1982 and 2008: ecological variability and regional differences. Environ. Res. Lett. 6:045501. doi: 10.1088/ 1748-9326/6/4/045501

Belay-Tedla, A., Zhou, X., Su, B., Wan, S., and Luo, Y. (2009). Labile, recalcitrant, and microbial carbon and nitrogen pools of a tallgrass prairie soil in the US great plains subjected to experimental warming and clipping. Soil Biol. Biochem. 41, 110-116.

Björk, R. G., Majdi, H., Klemedtsson, L., Lewis-Jonsson, L., and Molau, U. (2007). Long-term warming effects on root morphology, root mass distribution, and

\section{AUTHOR CONTRIBUTIONS}

TS and JM designed and established the field experiment and coordinated the day-to-day measurements, merged and analyzed the data and produced tables and figures. MR helped with site selection and production of birch plantlets together with EO and JM. KK and EO acquired funding. KM carried out phenology surveys, vegetation analysis, and soil moisture and temperature measurements. JM and KK planned in situ soil $\mathrm{CO}_{2}$ flux measurements, carried out by $\mathrm{KM}$ with a help from KK. KK and NM analyzed microbial biomass, calculated the $\mathrm{CO}_{2}$ flux results, and microbial biomass results. NM measured soil $\mathrm{C}$ and $\mathrm{N}$ concentrations, soil $\mathrm{CO}_{2}$ flux in the laboratory, and drafted the manuscript. O-MS measured root biomass. EM vascular plant shoot abundance. All authors contributed to interpretation of the findings, and participated in reviewing and editing of the manuscript.

\section{FUNDING}

This research was supported by the Academy of Finland (grant numbers 285030, 319952, and 316401), Kone Foundation (a personal grant to TS), and Helsinki Institute of Life Science (HiLIFE) (a HiLIFE Fellow Grant to KK covering, e.g., the salary of NM).

\section{ACKNOWLEDGMENTS}

We thank T. Ryynänen for designing and assembling the heating apparatus, N. Fontaine, T. Dubo, and M. Fontaneu for assisting in data collection, M. Lehtonen for analyzing $\mathrm{NH}_{4}$ and $\mathrm{NO}_{3}$ samples, $\mathrm{S}$. Savolainen for analysing soil $\mathrm{N}$ concentration, H. Fritze for supporting GC measurements, T. Kurten for language editing, and E. Karpoff, O. Suominen, I. Syvänperä, and E. Vainio for arranging facilities and assistance in the Kevo research station.

microbial activity in two dry tundra plant communities in northern Sweden. New Phytol. 176, 862-873. doi: 10.1111/j.1469-8137.2007.02231.x

Chen, R., Senbayram, M., Blagodatsky, S., Myachina, O., Dittert, K., Lin, X., et al. (2014). Soil $\mathrm{C}$ and $\mathrm{N}$ availability determine the priming effect: microbial $\mathrm{N}$ mining and stoichiometric decomposition theories. Global Change Biol. 20, 2356-2367. doi: $10.1111 /$ gcb. 12475

Conant, R. T., Steinweg, J. M., Haddix, M. L., Paul, E. A., Plante, A. F., and Six, J. (2008). Experimental warming shows that decomposition temperature sensitivity increases with soil organic matter recalcitrance. Ecology 89, 23842391.

Craine, J., Morrow, C., and Fierer, N. (2007). Microbial nitrogen limitation increases decomposition. Ecology 88, 2105-2113. doi: 10.1890/06-1847.1

Currano, E. D., Labandeira, C. C., and Wilf, P. (2010). Fossil insect folivory tracks paleotemperature for six million years. Ecol. Monogr. 80, 547-567. doi: 10.1890/ 09-2138.1

Dijkstra, F. A., and Cheng, W. (2007). Interactions between soil and tree roots accelerate long-term soil carbon decomposition. Ecol. Lett. 10, 1046-1053.

Dijkstra, F. A., Carrillo, Y., Pendall, E., and Morgan, J. A. (2013). Rhizosphere priming: a nutrient perspective. Front. Microbiol. 4:216. 
Elmendorf, S. C., Henry, G. H. R., Hollister, R. D., Bjork, R. G., BoulangerLapointe, N., Cooper, E. J., et al. (2012). Plot-scale evidence of tundra vegetation change and links to recent summer warming. Nat. Climate Change 2, 453-457.

Fan, Z., and Liang, C. (2015). Significance of microbial asynchronous anabolism to soil carbon dynamics driven by litter inputs. Sci. Rep. 5:9575. doi: 10.1038/ srep09575

Fontaine, S., Bardoux, G., Abbadie, L., and Mariotti, A. (2004). Carbon input to soil may decrease soil carbon content. Ecol. Lett. 7, 314-320.

Franzluebbers, A. J., and Arshad, M. A. (1997). Particulate organic carbon content and potential mineralization as affected by tillage and texture. Soil Sci. Soc. Am. J. 61, 1382-1386.

Friggens, N. L., Aspray, T. J., Parker, T. C., Subke, J.-A., and Wookey, P. A. (2020a). Spatial patterns in soil organic matter dynamics are shaped by mycorrhizosphere interactions in a treeline forest. Plant Soil 447, 521-535. doi: 10.1007/s11104-019-04398-y

Friggens, N. L., Hester, A. J., Mitchell, R. J., Parker, T. C., Subke, J.-A., and Wookey, P. A. (2020b). Tree planting in organic soils does not result in net carbon sequestration on decadal timescales. Global Change Biol. 26, 5178-5188. doi: $10.1111 / \mathrm{gcb} .15229$

Gedroc, J., McConnaughay, K., and Coleman, J. (1996). Plasticity in root/shoot partitioning: optimal, ontogenetic, or both? Functional Ecol. 10, 44-50. doi: $10.2307 / 2390260$

Hagedorn, F., Martin, M., Rixen, C., Rusch, S., Bebi, P., Zürcher, A., et al. (2010). Short-term responses of ecosystem carbon fluxes to experimental soil warming at the Swiss alpine treeline. Biogeochemistry 97, 7-19.

Hagen, S. B., Jepsen, J. U., Ims, R. A., and Yoccoz, N. G. (2007). Shifting altitudinal distribution of outbreak zones of winter moth Operophtera brumata in sub-arctic birch forest: a response to recent climate warming? Ecography 30, 299-307. doi: 10.1111/j.2007.0906-7590.04981.x

Harsch, M. A., Hulme, P. E., McGlone, M. S., and Duncan, R. P. (2009). Are treelines advancing? A global meta-analysis of treeline response to climate warming. Ecol. Lett. 12, 1040-1049. doi: 10.1111/j.1461-0248.2009.01355.x

Hartley, I., Garnett, M., Sommerkorn, M., Hopkins, D. W., Fletcher, B. J., Sloan, V. L., et al. (2012). A potential loss of carbon associated with greater plant growth in the European Arctic. Nat. Climate Change 2, 875-879.

Heikkinen, J., Ketoja, E., Nuutinen, V., and Regina, K. (2013). Declining trend of carbon in finnish cropland soils in 1974-2009. Global Change Biol. 19, 1456-1469. doi: $10.1111 / \mathrm{gcb} .12137$

Hobbie, S., and Chapin, F. (1998). The response of tundra plant biomass, aboveground production, nitrogen, and $\mathrm{CO}_{2}$ flux to experimental warming. Ecology 79, 1526-1544. doi: 10.1007/s00442-003-1198-3

Holtmeier, F.-K., and Broll, G. (2006). Radiocarbon-dated peat and wood remains from the finnish subarctic: evidence of treeline and landscape history. Holocene $16,743-751$.

IPCC (2014). "Climate change 2014: synthesis report," in Contribution of Working Groups I, II and III to the Fifth Assessment Report of the Intergovernmental Panel on Climate Change, eds R. K. Pachauri and L. A. Meyer (Geneva: IPCC), 151.

Janzen, H. H., Campbell, C. A., Brandt, S. A., Lafond, G. P., and Townley-Smith, L. (1992). Light-fraction organic matter in soils from long-term crop rotations. Soil Sci. Soc. Am. J. 56, 1799-1806.

Jepsen, J. U., Hagen, S. B., Ims, R. A., and Yoccoz, N. G. (2008). Climate change and outbreaks of the geometrids Operophtera brumata and Epirrita autumnata in subarctic birch forest: evidence of a recent outbreak range expansion. J. Animal Ecol. 77, 257-264. doi: 10.1111/j.1365-2656.2007.01339.x

Jia, J., Cao, Z., Liu, C., Zhang, Z., Lin, L., Wang, Y., et al. (2019). Climate warming alters subsoil but not topsoil carbon dynamics in alpine grassland. Global Change Biol. 25, 4383-4393. doi: 10.1111/gcb.14823

Kammer, A., Hagedorn, F., Shevchenko, I., Leifeld, J., Guggenberger, G., Goryacheva, T., et al. (2009). Treeline shifts in the Ural mountains affect soil organic matter dynamics. Global Change Biol. 15, 1570-1583. doi: 10.1111/j. 1365-2486.2009.01856.x

Kätterer, T., Reichstein, M., Andrén, O., and Lomander, A. (1998). Temperature dependence of organic matter decomposition: a critical review using literature data analyzed with different models. Biol. Fertil. Soils 27, 258-262.

Kaukonen, M., Ruotsalainen, A. L., Wäli, P. R., Männistö, M. K., Setälä, H., Saravesi, $\mathrm{K}$., et al. (2013). Moth herbivory enhances resource turnover in subarctic mountain birch forests? Ecology 94, 267-272. doi: 10.1890/12-0917.1
Kirschbaum, M. U. F. (1995). The temperature dependence of soil organic matter decomposition, and the effect of global warming on soil organic C storage. Soil Biol. Biochem. 27, 753-760. doi: 10.1016/0038-0717(94)00242-s

Körner, C., and Paulsen, J. (2004). A world-wide study of high altitude treeline temperatures. J. Biogeogr. 31, 713-732.

Kozlov, M. (2008). Losses of birch foliage due to insect herbivory along geographical gradients in Europe: a climate-driven pattern? Climatic Change 87, 107-117. doi: 10.1007/s10584-007-9348-y

Kozlov, M. V., Stekolshchikov, A. V., Söderman, G., Labina, E. S., Zverev, V., and Zvereva, E. L. (2015). Sap-feeding insects on forest trees along latitudinal gradients in northern Europe: a climate-driven patterns. Global Change Biol. 21, 106-116. doi: $10.1111 / \mathrm{gcb} .12682$

Kristensen, J. Å, Rousk, J., and Metcalfe, D. B. (2020). Below-ground responses to insect herbivory in ecosystems with woody plant canopies: a meta-analysis. J. Ecol. 108, 917-930. doi: 10.1111/1365-2745.13319

Kristensen, J. A., Metcalfe, D. B., and Rousk, J. (2018). The biogeochemical consequences of litter transformation by insect herbivory in the Subarctic: a microcosm simulation experiment. Biogeochemistry 138, 323-336.

Kuzyakov, Y., Friedel, J. K., and Stahr, K. (2000). Review of mechanisms and quantification of priming effects. Soil Biol. Biochem. 32, 1485-1498. doi: 10. 1016/s0038-0717(00)00084-5

Lefèvre, R., Barré, P., Moyano, F. E., Christensen, B. T., Bardoux, G., Eglin, T., et al. (2014). Higher temperature sensitivity for stable than for labile soil organic carbon - evidence from incubations of long-term bare fallow soils. Global Change Biol. 20, 633-640. doi: 10.1111/gcb.12402

Lloyd, J., and Taylor, J. A. (1994). On the temperature dependence of soil respiration. Functional Ecol. 8, 315-323.

Lundin, E. J., Klaminder, J., Giesler, R., Persson, A., Olefeldt, D., Heliasz, M., et al. (2016). Is the subarctic landscape still a carbon sink? Evidence from a detailed catchment balance. Geophys. Res. Lett. 43:1998.

Mäkipää, R., Häkkinen, M., Muukkonen, P., and Peltoniemi, M. (2008). The costs of monitoring changes in forest soil carbon stocks. Boreal Environ. Res. 13, $120-130$.

Marañón-Jiménez, S., Peñuelas, J., Richter, A., Sigurdsson, B. D., Fuchslueger, L., Leblans, N. I. W., et al. (2019). Coupled carbon and nitrogen losses in response to seven years of chronic warming in subarctic soils. Soil Biol. Biochem. 134, 152-161. doi: 10.1016/j.soilbio.2019.03.028

Meyer, N., Silfver, T., Karhu, K., Myller, K., Sietiö, O.-M., Myrsky, E. (2021). Strong interactive effects of warming and insect herbivory on soil carbon and nitrogen dynamics at Subarctic tree line. Front. For. Glob. Change. doi: 10.5061/dryad. fqz612jtg

Meyer, N., Welp, G., and Amelung, W. (2018). The temperature sensitivity (Q10) of soil respiration: controlling factors and spatial prediction at regional scale based on environmental soil classes. Global Biogeochem. Cycles 32, 306-323.

Mikan, C. J., Schimel, J. P., and Doyle, A. P. (2002). Temperature controls of microbial respiration in arctic tundra soils above and below freezing. Soil Biol. Biochem. 34, 1785-1795.

Moorhead, D. L., and Sinsabaugh, R. L. (2006). A theoretical model of litter decay and microbial interaction. Ecol. Monogr. 76, 151-174. doi: 10.1890/00129615(2006)076[0151:atmold]2.0.co;2

Murphy, C. J., Baggs, E. M., Morley, N., Wall, D. P., and Paterson, E. (2015). Rhizosphere priming can promote mobilisation of $\mathrm{N}$-rich compounds from soil organic matter. Soil Biol. Biochem. 81, 236-243. doi: 10.1016/j.soilbio.2014.11. 027

Natali, S. M., Schuur, E. A. G., Trucco, C., Hicks Pries, C. E., Crummer, K. G., and Baron Lopez, A. F. (2011). Effects of experimental warming of air, soil and permafrost on carbon balance in Alaskan tundra. Global Change Biol. 17, 1394-1407. doi: 10.1111/gcb.13204

Neuvonen, S., Niemelä, P., and Virtanen, T. (1999). Climatic change and insect outbreaks in boreal forests: the role of winter temperatures. Ecol. Bull. 47, 63-67.

Oechel, W., Hastings, S., Vourlrtis, G., Jenkins, M., Riechers, G., and Grulke, N. (1993). Recent change of Arctic tundra ecosystems from a net carbon dioxide sink to a source. Nature 361, 520-523. doi: 10.1038/361520a0

Parker, C. T., Subke, J.-A., and Wookey, P. A. (2015). Rapid carbon turnover beneath shrub and tree vegetation is associated with low soil carbon stocks at a subarctic treeline. Global Change Biol. 21, 2070-2081. doi: 10.1111/gcb.12 793 
Poeplau, C., Vos, C., and Don, A. (2017). Soil organic carbon stocks are systematically overestimated by misuse of the parameters bulk density and rock fragment content. Soil 3, 61-66. doi: 10.5194/soil-3-61-2017

Pouliot, D., Latifovic, R., and Olthof, I. (2009). Trends in vegetation NDVI from 1 $\mathrm{km}$ AVHRR data over Canada for the period 1985-2006. Int. J. Remote Sensing 30, 149-168. doi: 10.1080/01431160802302090

Powlson, D. S., Brookes, P. C., and Christensen, B. T. (1987). Measurement of soil microbial biomass provides an early indication of changes in total soil organic matter due to straw incorporation. Soil Biol. Biochem. 19, 159-164. doi: 10.1016/0038-0717(87)90076-9

Qian, H., Joseph, R., and Zeng, N. (2010). Enhanced terrestrial carbon uptake in the northern high latitudes in the 21st century from the coupled carbon cycle climate model intercomparison project model projections. Global Change Biol. 16, 641-656. doi: 10.1111/j.1365-2486.2009.01989.x

Richardson, S. J., Press, M. C., Parsons, A. N., and Hartley, S. E. (2002). How do nutrients and warming impact on plant communities and their insect herbivores? A 9-year study from a sub-Arctic heath. J. Ecol. 90, 544-556.

Robertson, G. P., Coleman, D. C., Bledsoe, C. S., and Sollins, P. (1999). Standard Soil Methods for Long-Term Ecological Research. New York, NY: Oxford University Press.

Rousi, M., Possen, B. J. M. H., Ruotsalainen, S., Silfver, T., and Mikola, J. (2018). Temperature and soil fertility as regulators of tree line scots pine growth and survival - implications for the acclimation capacity of northern populations. Global Change Biol. 24, e545-e559. doi: 10.1111/gcb.13956

Rousk, J., and Frey, S. D. (2015). Revisiting the hypothesis that fungal-to-bacterial dominance characterizes turnover of soil organic matter and nutrients. Ecol. Monogr. 85, 457-472.

Rundqvist, S., Hedenås, H., Sandström, A., Emanuelsson, U., Eriksson, H., Jonasson, C., et al. (2011). Tree and shrub expansion over the past 34 years at the tree-line near Abisko, Sweden. Ambio 40, 683-692. doi: 10.1007/s13280011-0174-0

Schrumpf, M., Schulze, E. D., Kaiser, K., and Schumacher, J. (2011). How accurately can soil organic carbon stocks and stock changes be quantified by soil inventories? Biogeosciences 8:1193. doi: 10.1073/pnas.1002592107

Silfver, T., Autelo, M., Paaso, U., Koikkalainen, K., and Mikola, J. (2013). Use of an insecticide in field-scale plant-herbivore studies: no side effects of synthetic pyrethrin on Betula pendula growth or chemistry. Anna. Botanici Fennici 50, 337-346.

Silfver, T., Heiskanen, L., Aurela, M., Myller, K., Karhu, K., Meyer, N., et al. (2020). Insect herbivory dampens subarctic birch forest $\mathrm{C}$ sink response to warming. Nat. Commun. 11:2529. doi: 10.1038/s41467-020-16404-4

Simpson, A. J., Simpson, M. J., Smith, E., and Kelleher, B. P. (2007). Microbially derived inputs to soil organic matter: are current estimates too low? Environ. Sci. Technol. 41, 8070-8076. doi: 10.1021/es071217x

Sistla, S. A., Moore, J. C., Simpson, R. T., Gough, L., Shaver, G. R., and Schimel, J. P. (2013). Long-term warming restructures Arctic tundra without changing net soil carbon storage. Nature 497, 615-619. doi: 10.1038/nature12129

Sparling, G. P., Feltham, C. W., Reynolds, J., West, A. W., and Singleton, P. (1990). Estimation of soil microbial $\mathrm{c}$ by a fumigation-extraction method: use on soils of high organic matter content, and a reassessment of the kec-factor. Soil Biol. Biochem. 22, 301-307. doi: 10.1016/0038-0717(90)90104-8

Stark, S., Väisänen, M., Ylänne, H., Julkunen-Tiitto, R., and Martz, F. (2015). Decreased phenolic defence in dwarf birch (betula nana) after warming in subarctic tundra. Polar Biol. 38, 1993-2005.
Tømmervik, H., Johansen, B., Tombre, I., Thannheiser, D., Høgda, K. A., Gaare, E., et al. (2004). Vegetation changes in the nordic mountain birch forest: the influence of grazing and climate change. Arctic Antarctic Alpine Res. 36, 323-332. doi: 10.1657/1523-0430(2004)036[0323:vcitnm]2.0.co;2

Van Bogaert, R., Haneca, K., Hoogesteger, J., Jonasson, C., De Dapper, M., and Callaghan, T. V. (2011). A century of tree line changes in sub-Arctic Sweden show local and regional variability and only a minor role of 20th century climate warming. J. Biogeogr. 38, 907-921.

Vance, E. D., Jenkinson, D. S., and Brookes, P. C. (1987). An extraction method for measuring soil microbial biomass C. Soil Biol. Biochem. 19, 703-707. doi: 10.1007/s00248-004-0164-x

Wilmking, M., Harden, J., and Tape, K. (2006). Effect of tree line advance on carbon storage in NW Alaska. J. Geophys. Res. 111:G2.

Wolf, A., Kozlov, M. V., and Callaghan, T. V. (2008). Impact of non-outbreak insect damage on vegetation in northern Europe will be greater than expected during a changing climate. Climatic Change 87, 91-106. doi: 10.1007/s10584-007-9 340-6

Xu, X., Sherry, R. A., Niu, S., Zhou, J., and Luo, Y. (2012). Long-term experimental warming decreased labile soil organic carbon in a tallgrass prairie. Plant Soil 361, 307-315.

Ylänne, H., Stark, S., and Tolvanen, A. (2015). Vegetation shift from deciduous to evergreen dwarf shrubs in response to selective herbivory offsets carbon losses: evidence from 19 years of warming and simulated herbivory in the subarctic tundra. Global Change Biol. 21, 3696-3711. doi: 10.1111/gcb. 12964

Zhang, X. Y., Meng, X. J., Gao, L. P., Sun, X. M., Fan, J. J., and Xua, L. J. (2010). Potential impacts of climate warming on active soil organic carbon contents along natural altitudinal forest transect of Changbai mountain. Acta Ecol. Sin. 30, 113-117. doi: 10.1016/j.chnaes.2010.03.011

Zimmermann, M., Meir, P., Silman, M. R., Fedders, A., Gibbon, A., Malhi, Y., et al. (2010). No differences in soil carbon stocks across the tree line in the peruvian andes. Ecosystems 13, 62-74.

Zvereva, E. L., Zverev, V., and Kozlov, M. V. (2012). Little strokes fell great oaks: minor but chronic herbivory substantially reduces birch growth. Oikos 121, 2036-2043.

Conflict of Interest: The authors declare that the research was conducted in the absence of any commercial or financial relationships that could be construed as a potential conflict of interest.

Publisher's Note: All claims expressed in this article are solely those of the authors and do not necessarily represent those of their affiliated organizations, or those of the publisher, the editors and the reviewers. Any product that may be evaluated in this article, or claim that may be made by its manufacturer, is not guaranteed or endorsed by the publisher.

Copyright (c) 2021 Meyer, Silfver, Karhu, Myller, Sietiö, Myrsky, Oksanen, Rousi and Mikola. This is an open-access article distributed under the terms of the Creative Commons Attribution License (CC BY). The use, distribution or reproduction in other forums is permitted, provided the original author(s) and the copyright owner(s) are credited and that the original publication in this journal is cited, in accordance with accepted academic practice. No use, distribution or reproduction is permitted which does not comply with these terms. 